\title{
How to exhibit a human mummy in a former monastery? The case of the body of Michael Willmann (1630-1706)
}

\author{
Andrzej Kozieł
}

\author{
Prof. Dr hab. Andrzej Kozieł \\ University of Wroclaw \\ Institute of Art History \\ ul. Szewska 36 \\ 50-139 Wrocław \\ Poland \\ e-mail: andrzej.koziel@uwr.edu.pl
}

Mureológia a kultúrne dedičstvo, 2020, 8:4:95-109
DOI: 10.46284/mkd.2020.8.4.7

How to exhibit a buman mummy in a former monastery? The case of the body of Michael Willmann (1630-1706)

This paper discusses the mummified body of Michael Willmann (1630-1706) - one of the most outstanding painters of the Baroque period in Central Europe. Willmann's mummy was preserved in the crypt of the former Cistercian monastery church in Lubiaż, Silesia (Poland). The article presents the history of the mummy and possibilities for opening the crypt and displaying it to the public, following the example of similar expositions in Europe which have found respectful and sensitive solutions for presenting the bodies of the deceased (e.g. Capuchin Crypt in Palermo and Capuchin Church in Brno). Willmann's mummy is not only the body of an artist, but also a part of the cultural heritage of the Lubiąż Cistercians, making it worthy museification. This issue is particularly important in the context of the plans for establishing the Michael Willmann Museum in the former Cistercian monastery church in Lubiąż.

Keywords: Michael Willmann, mummy, the monastery crypt, Lubiąż, Cistercians, exposition

When, in 1738, the monks from the Cistercian monastery in Lubiaż in Silesia (Poland) went down to the crypt and opened the coffin of Michael Willmann, one of the most outstanding painters of the Baroque era in Central Europe ${ }^{1}$ who had died in 1706 and was entombed among the deceased monks in recognition of his artistic contributions to the monastery, they could not believe their eyes. After his death, the artist's body had been placed in the crypt, where it had been preserved in an almost perfect condition. As described in the chronicle of Lubiąż Abbey, Historia Domestica Lubensis, the torso, head, legs and especially the arms remained "exceptionally intact and only in some places, by common law, turned to ashes". 2 The condition of Willmann's body was considered by the Cistercian monks to be almost a miracle which

\footnotetext{
${ }^{1}$ For more on the life and work of Michael Willmann, see: KOZIEŁ, Andrzej. Michael Willmann i jego malarska pracownia. Wrocław: Wydawnictwo Uniwersytetu Wrocławskiego 2013 (“Acta Universitatis Wratislaviensis”, 3463, Historia Sztuki, 33), with earlier literature.

2 "Extraordinarie Solidum et vix alicubi lege communi in pulverem reversum." Historia domestica Lubensis Notitiis praeclaris repleta Conscripta à Reverendo P. Arnoldo Professo Lubensi p: $t:$ S.S. Theologiae Professore. [Leubus 1759], Wrocław, Biblioteka Uniwersytecka, manuscript, sign. IV F. 209, p. 104.
} 
proved his true conversion to Catholicism. ${ }^{3}$

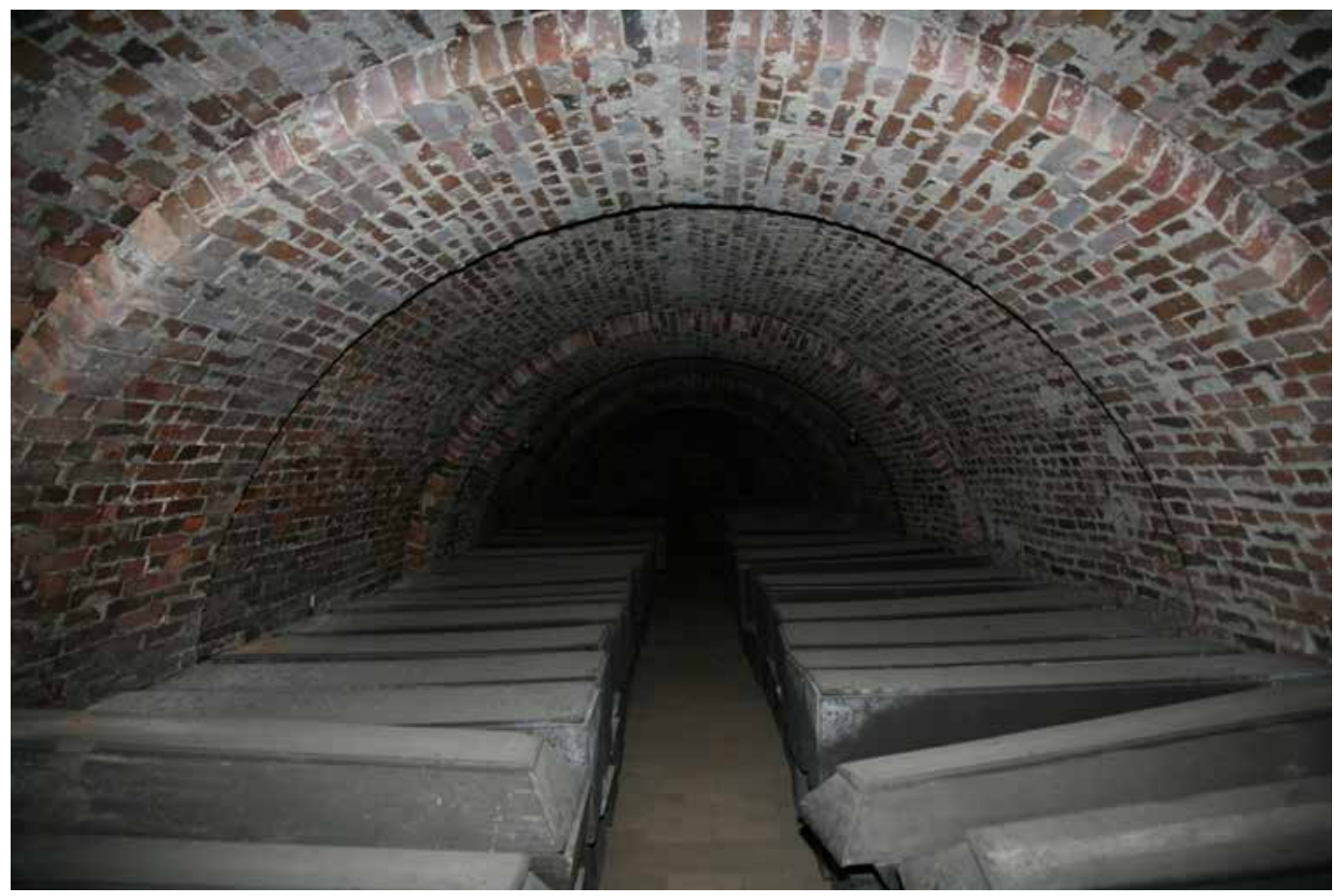

Figure 1: View of interior of the monastery crypt in the former Cistercian church in Lubiaz:

Photograph by Martin Mádl

The mummified body of Willmann has fortunately survived to our times and is still located in the crypt of the former Cistercian monastery church in Lubiąz $\dot{z}^{4}$ (Figure 1). It is undoubtedly a cultural attraction of this place and a worldwide phenomenon, as it is the only such case known of among the great artists of the Baroque period. Unfortunately, although the monastery has not had a sacred function since 1940 and the entire Cistercian Abbey complex has been opened to the public since 1989, the crypt is closed and excluded from the tour. This is because Willmann's mummy is currently treated exclusively as the body of a deceased person. However, is this the only possible solution? The aim of this article is to show that although the mummified corpse of the artist deserves respect as the mortal remains of a deceased person, it

\footnotetext{
${ }^{3}$ According to a record in the preserved family chronicle of Willmann, the artist, who was born and raised in Königsberg in a Lutheran family, converted to the Catholic religion on 22 May 1663 in Kłodzko. See: Michael Willmann's family chronicle. In: RIVIUS, Gualtherus Hermenius. Der furnembsten notwendigsten der gantzen Architektur angehärigen mathematischen und mechanischen Künst eygentlicher Bericht und verstendliche Unterrichtung. Nürnberg: Peterius 1547, Prague, Strahovská knihovna, sign. AY XII 15.

${ }^{4}$ So far, the body of Michael Willmann has been mentioned in: WELS, Paul. Kloster Leubus in Schlesien. Breslau: Buchdruckerei der Schlesischen Volkszeitung 1909, p. 54; FUHRMANN, Heinrich. Ich fotografierte Michael Willmann. In: Der Scblesier, 18, 1966, no. 4, p. 5; MISZKIEWICZ, Brunon. Identyfikacja szczątków Michaela Willmanna w krypcie kościoła poklasztornego w Lubiążu. In: KALETYN, Tadeusz (ed.). Lubią̇, klasz̨tor Cystersów. Wyniki badań z lat 1988-89. Wrocław: Wojewódzki Ośrodek Archeologiczno-Konserwatorski we Wrocławiu 1990, p. 15-18; KACZMAREK, Romuald, WITKOWSKI, Jacek. Michat L.E. Willmann. Informacje dotyczace sycia oraz pochówku w krypcie kościoła cysterskiego w Lubiqżu, In: KALETYN, Tadeusz (ed.). Lubiaż, klasztor Cystersón. Wyniki badań z lat 1988-89. Wrocław: Wojewódzki Ośrodek Archeologiczno-Konserwatorski we Wrocławiu 1990, p. 26-31; KOZIEL, ref. 1, p. 32-36.
} 
is also part of the cultural heritage of the Lubiąż Cistercians and could be treated as a potential museum exhibit.

\section{I}

Michael Willmann died in Lubiąż on 26 August 1706 at the age of 76. The exact date of his death was meticulously recorded in the local Cistercian Abbey's register of the deceased, Necrologium Lubense. ${ }^{5}$ After the funeral ceremony, the Willmann's body was, as an exception,

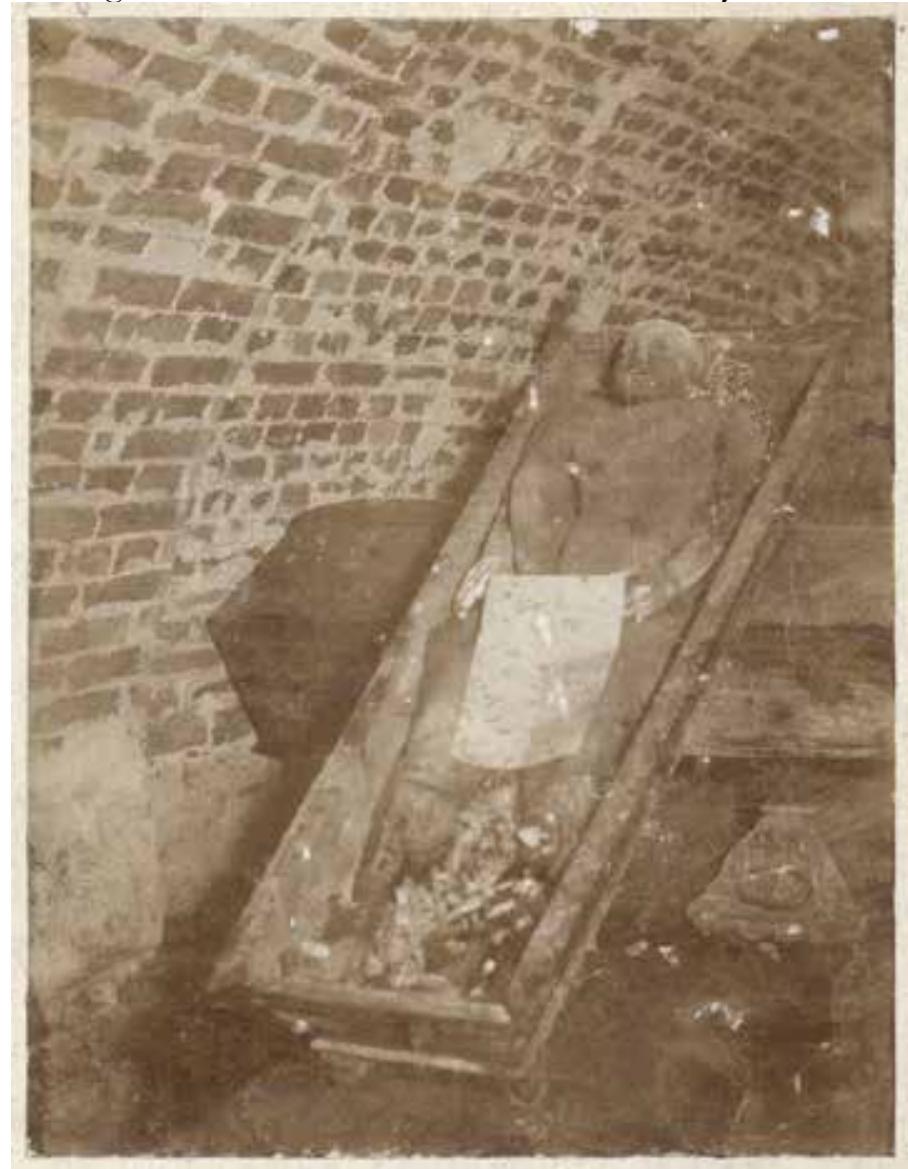

Figure 2: The mummified body of Michael Willmann: its condition in 1901 or 1902. Photograph by Herder-Institut, Marburg, sign. 47977 placed in the monastic crypt located in the northern nave of the monastic church of the Assumption of Blessed Virgin Mary in Lubiąż. This church was built during the baroquisation of a Gothic church in 1672-1680, and subsequently served as a new burial place for Cistercian monks. The particular conditions in the crypt, where there is constant air circulation and low humidity, caused the bodies of the deceased monks and Willmann to undergo mummification. As mentioned above, this was noticed as early as 1738 , when the coffin with his body was first opened. In later years, the coffin holding the artist's corpse was opened many times. In 1901 (or 1902), it was opened by Jakob Caro, a Professor of History at the University of Wrocław. Importantly, during his visit to the monastic crypt, he took the earliest known photograph, showing the artist's mummy in its entirety ${ }^{6}$ (Figure

2). It confirms previous textual accounts that the dressed corpse of Willmann, entombed in the monastery crypt, was completely mummified. What is more, it was in very good condition at that time, had suffered no major damage, and its authenticity was confirmed by a certificate

\footnotetext{
5 “26. Augusti. / Item a. 1706 ob. Michael Leopoldus / Willmann, Pruthenus Regiomontanus, / expletis fere 76 aetatis annuis, / a picturae excellentia temporum / nostrum Apelles, et Ecclesiae / hujatis insignis splendor ultra / 40 annos iucola Lubensis et / Familiaris noster”. See: Necrologium Lubense. Wrocław, Biblioteka Uniwersytecka, manuscipt, sign. IV. Fol. 214.

${ }^{6}$ The photograph taken at that time has been preserved in Günther Grundmann's archive at the Herder-Institut in Marburg (ref. 47977 and 47977a) and in the collections of the State Archive in Wrocław. See: KACZMAREK, WITKOWSKI, ref. 4, p. 27.
} 
located between the artist's hands. To protect it from moisture and mechanical damage, the coffin was lined with wood shavings.

Unfortunately, the Second World War and the first post-war years were not kind to Willmann's mummy. The decision taken by the German authorities at the end of August 1944 to use the crypt as a storage area for works of art was of key importance to its fate. ${ }^{7}$ By hiding the artworks in a religious crypt, the Germans hoped to protect them against potential destruction or theft by Red Army, which was approaching from the east. However, this ruse did not protect them from theft. After Lubiąż was occupied by the Red Army on 25 January 1945, the crypt was plundered many times and its contents were removed. What is worse, during these

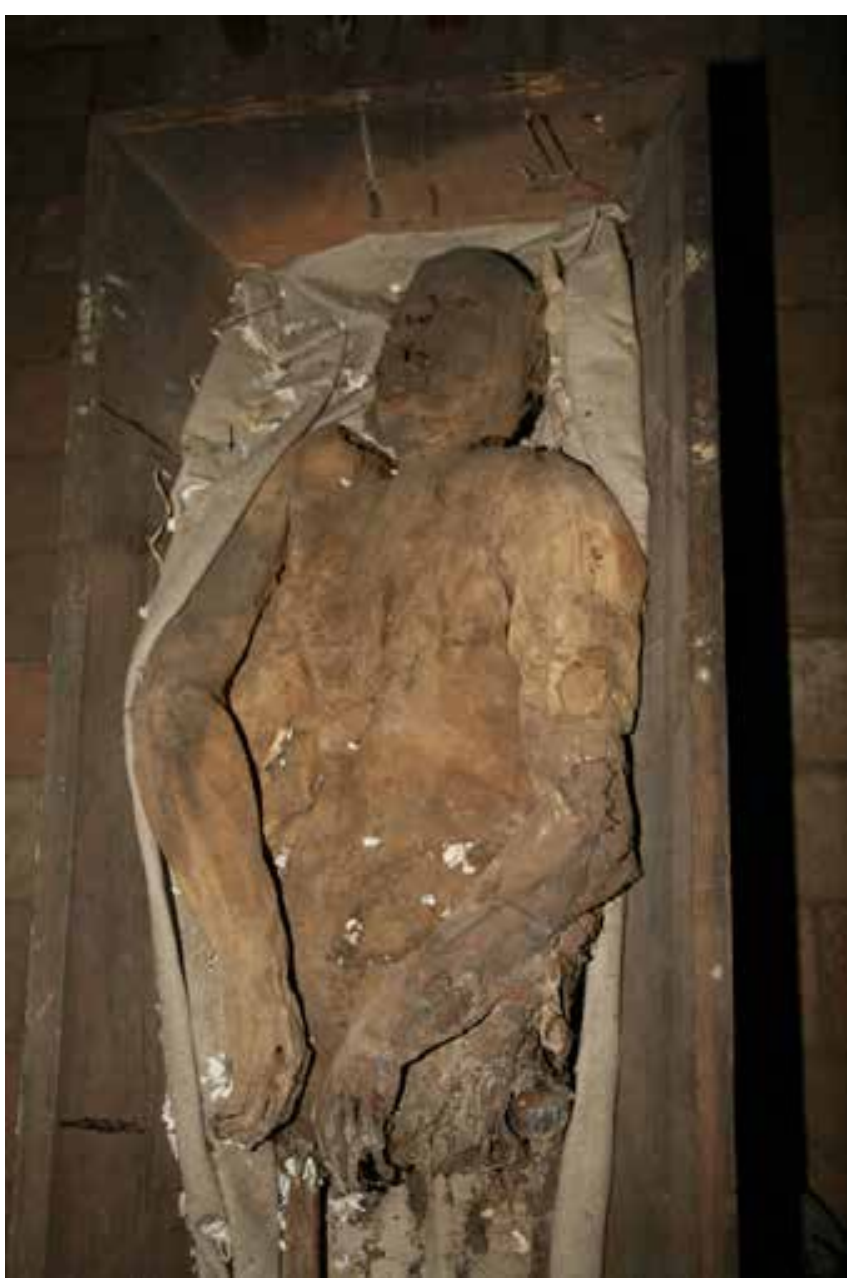

Figure 3: The mummified body of Michael Willmann: current condition.

Photograph by Martin Mádl robberies, the mummified corpses of the monks and Willmann suffered greatly, as they were pulled out of their coffins, desecrated, burned and chopped. This situation did not end when the Soviet troops left the Cistercian Abbey in late 1947: the crypt continued to be plundered and the coffins with the corpses in them were destroyed.

This situation changed only in 1989, when the former abbey was taken over by the Lubiąz Foundation. It was then, on the initiative of the then Provincial Archaeological and Conservation Centre in Wrocław, that a team of scientists was established, which in July 1989 carried out complex archaeological and anthropological cleaning works in the monastic crypt. ${ }^{8}$ The mummified body of Willmann was identified on the basis of a pre-war photograph. It was found in the western part of the crypt in a damaged coffin, located together with the bones of three monks and covered with rubble, wooden shavings and rubbish. Unfortunately, the mummy had been significantly damaged during the period of looting and devasta-

\footnotetext{
${ }^{7}$ For more on this subject, see: KOZIEL, Andrzej. Losy wyposażenia i wystroju kościoła klasztornego Wniebowzięcia NMP w Lubiążu po 1943 roku. In: KOZIEŁ, Andrzej (ed.). Kościót klasz̨torny Wniebowzięcia NMP w Lubiażu. Historia - stan zachowania - koncepcja rewitalizacji, Wrocław: Wydawnictwo Uniwersytetu Wrocławskiego 2010, p. 137-138. ${ }^{8}$ KALETYN, Tadeusz. Prace porządkowe archeologiczno-antropologiczne w krypcie grobowej w kościele NMP w Lubiążu. In: KALETYN, Tadeusz (ed.). Lubiaż, klasz̧tor Cystersów. Wyniki badań z lat 1988-89. Wrocław: Wojewódzki Ośrodek Archeologiczno-Konserwatorski we Wrocławiu 1990, p. 6-8.
} 


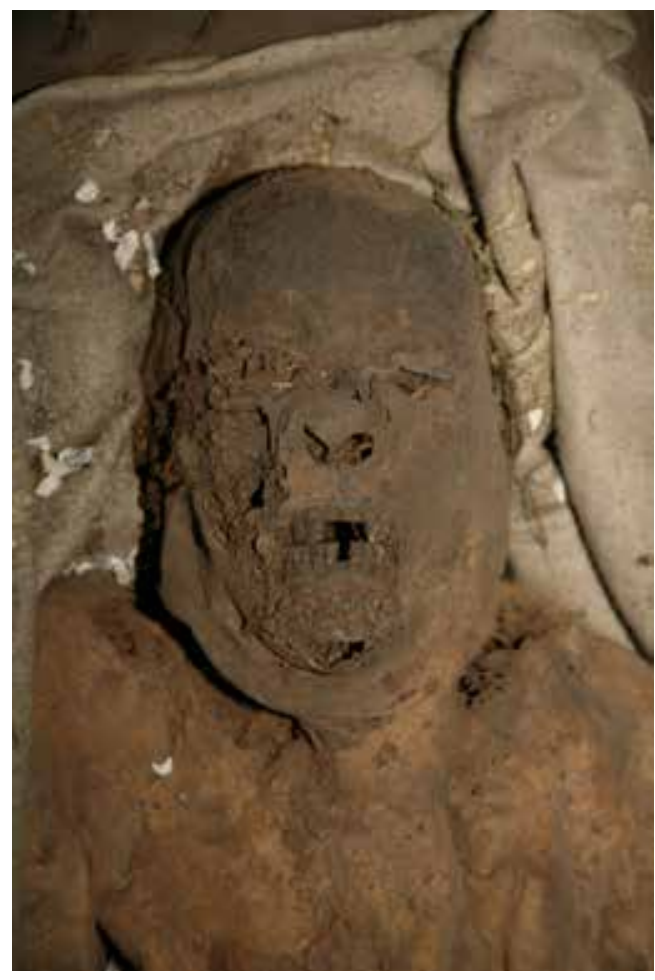

Figure 4: The mummified body of Michael Willmann-head, current condition. Photograph by Martin Mádl

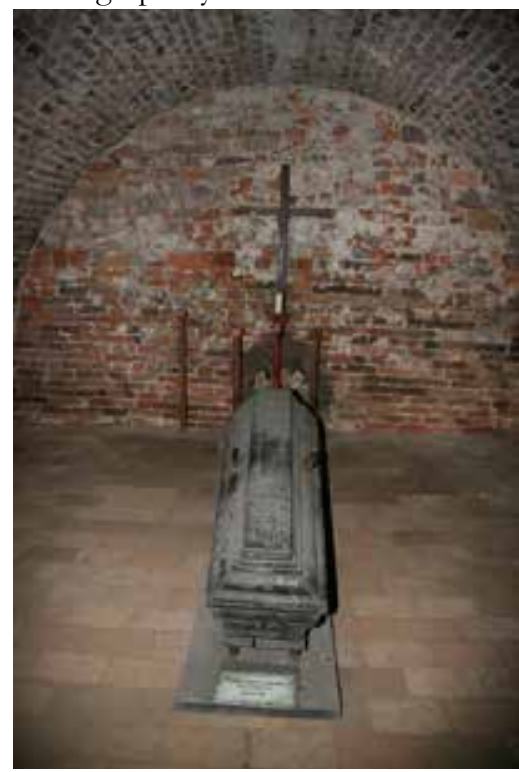

Figure 6: The coffin with the mummified body of Michael Willmann, current condition.

Photograph by Martin Mádl

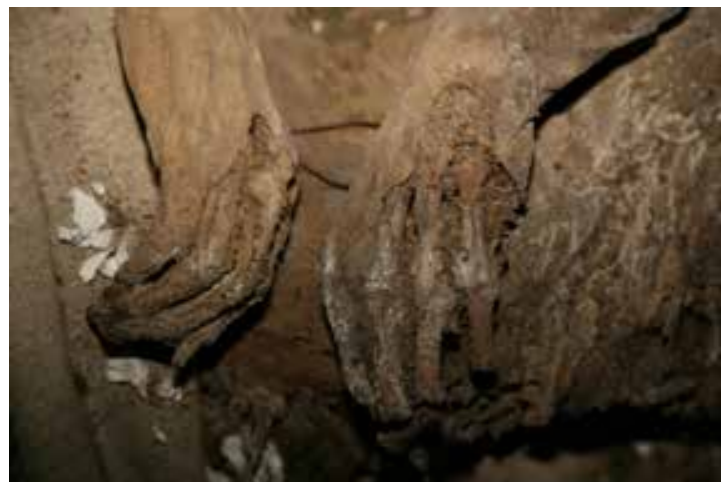

Figure 5: The mummified body of Michael Willmannhands, the current condition.

Photograph by Martin Mádl

tion of the crypt after 1945 it (Figure 3). In its lower part, from the waist down, the mummified soft tissues and clothing were irretrievably destroyed, and only a bare skeleton without tarsal bones remained. However, the upper part of the body, including the chest, head and hands, were fortunately preserved in their mummified state, in a comparable condition to that of the pre-war period. Minor damage to the mummified tissue and clothing had occurred only in the upper part of the skull and on the finger bones (Figs 4 and 5). After cleaning, Willmann's mummy was wrapped in linen canvas and placed in a new wooden coffin, in which a new document confirming its authenticity was also placed. ${ }^{9}$ To honour the artist, who is sometimes referred to as the "Silesian Apelles", the coffin was placed in an prominent place, in the middle of the western part of the crypt, on a board with his given names, surname and dates of his birth and death (Figure 6).

\section{II}

Currently, in the monastic crypt, Willmann's coffin is located alongside 101 wooden coffins (90 new and 11 reconstructed Baroque ones) containing the mortal remains of Cistercian monks. They are arranged in two rows, partly one on top of the other, across a narrow brick five-span crypt, which is $5 \mathrm{~m}$ wide, $3 \mathrm{~m}$ high and $27.5 \mathrm{~m}$ long and is covered with a barrel vault. The crypt has wide perforated air vents in its northern wall in the middle of each bay which provide adequate air circulation. The space between

${ }^{9}$ Ibid., Fig. 5. 


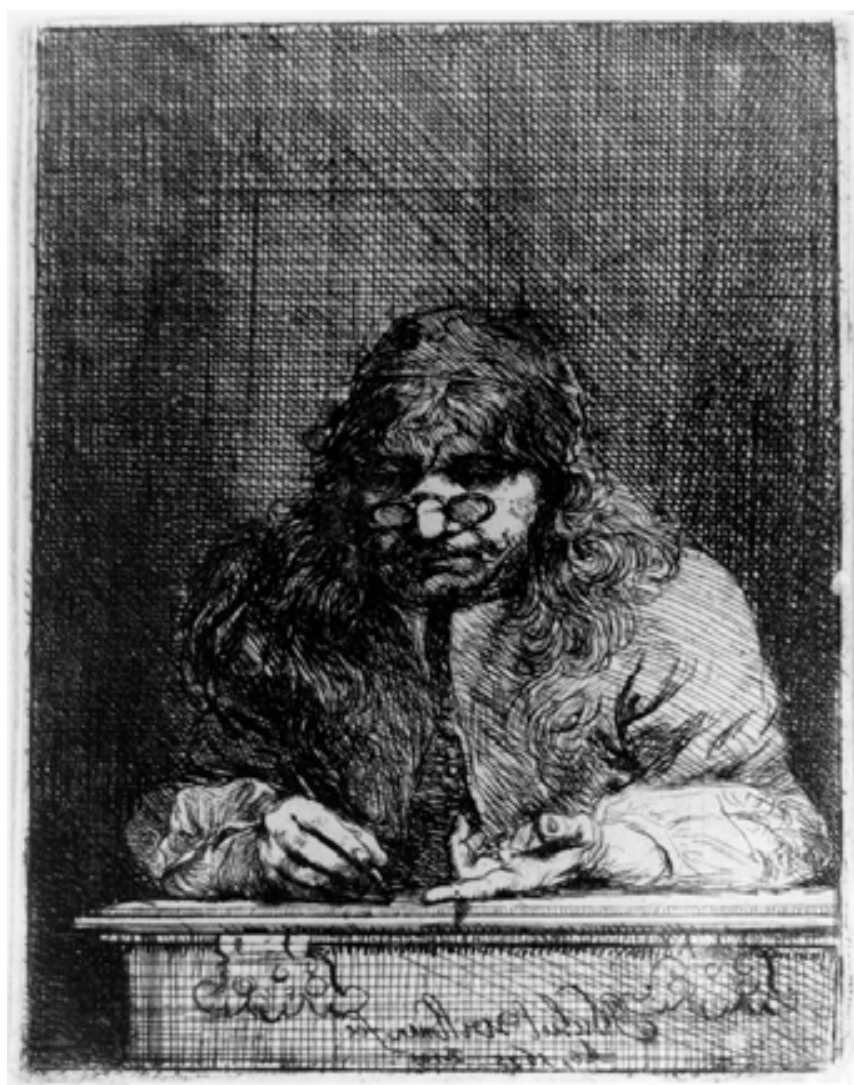

Figure 7: Self portrait of Michael Willmann, made in 1675, etched, printed on paper. The print belongs to Muzeum Narodowe in Warsaw. Photograph by Muzeum Narodowe in Warsaw

the two rows of coffins with the bodies of monks creates a narrow passageway that leads to the western part of the crypt, where the coffin with Willmann's mummy is located. It is separated from the other coffins and positioned along the crypt at its western wall, on which a wooden cross was placed.

During the maintenance works in the crypt, the corpses of 93 monks were completed. The remains (mainly upper and lower limbs) of about 30 people remained which could not be matched to any of the arranged corpses. ${ }^{10}$ The completed bodies of the monks are in various states of preservation. Only some of them survived in a mummified form with no cavities and a full skeleton. Most of them bear traces of the damage that occurred on the occasions when the crypt was plundered after 1945 . Of these corpses, arranged by anthropologists, many are partly deprived of the already mummified soft tisof the already

sues and clothing and have incomplete skeletons (mainly lacking skulls).

The bodies of the monks of the Cistercian monastery in Lubiazz were entombed in the crypt from around 1680. A full list of the crypt's inhabitants is contained in the aforementioned Necrologium Lebense, which was begun in 1615 and was kept until the monastery was closed down in $1810 .{ }^{11}$ It shows that, together with regular monks, the crypt held abbots and priors of the abbey. At present, however, it is very difficult to identify their bodies due to significant damage to the corpses and the theft of a large proportion of the accompanying objects which were usually placed in the coffin together with the body during funeral ceremonies. At present, we can identify the mummified bodies of only one prior and one abbot with high probability, based on the provenance of the objects found near them during the maintenance works in the crypt. ${ }^{12}$ In the tomb marked with the number 62 lies the well-preserved mummy of Prior Albericus Hilbrich (d. 1737). The similarly well-preserved mummy of abbot Johannes Reich (d.

\footnotetext{
${ }^{+}$MISZKIEWICZ, Brunon. Raport zprac porzqdkowo-segregacyjnych zmumifikowanych zwtok w kerypcie $w$ kościele NMP $w$ Lubiażu. In: KALETYN, Tadeusz (ed.). Lubiqż, klasžtor Cystersów. Wyniki badań z lat 1988-89. Wrocław: Wojewódzki Ośrodek Archeologiczno-Konserwatorski we Wrocławiu 1990, p. 9-14.

${ }^{11}$ See: Necrologium Lubense..., ref. 5.

${ }^{12}$ WITKOWSKI, Jacek. Inwentarz zabytków ruchomych odkrytych w krypcie kościoła pocysterskiego w Lubiążu. In: KALETYN, Tadeusz (ed.). Lubiqż, klasztor Cystersów. Wyniki badań z lat 1988-89. Wrocław: Wojewódzki Ośrodek Archeologiczno-Konserwatorski we Wrocławiu 1990, p. 32-52.
} 
1691) was laid in tomb marked number 64. He was one of Willmann's greatest patrons and the initiator of the Baroque reconstruction of the Abbey in Lubiaż.

Although the former abbey has been open to the public since 1989, the monastic crypt is, as mentioned above, closed and excluded from the tour. ${ }^{13}$ Entrance to the crypt is permitted by the Lubiąż Foundation only for research purposes. This decision, which was made by the owner of the facility, was dictated by the fact that the crypt, which underwent maintenance after the devastation it suffered post-war, is considered to be the final resting place for the monks and Willmann.

The monastic crypt is currently the only room of this status in the whole Lubiaz Abbey complex. Since it was closed down in 1810, the monastic building was no longer used by the monks. ${ }^{14}$ The monastery church was turned into a parish church and functioned as such until 1940. After 1817, the Abbot's Palace housed a horse stable, while the monastery itself has served as a hospital for the mentally ill since 1823. During World War II, the monastery buildings were used as a resettlement centre and internment location, and from 1943 as a research and implementation centre for the German army. ${ }^{15}$ As it is known, in 1945 the building was taken over by the Russians, who set up a military hospital in the monastery's premises. After 1948, the Abbey's buildings were abandoned and it was not until 1956 that some of them were turned into a storehouse for books and works of art. Nowadays, more than thirty years after the acquisition of the building by the Lubiąz Foundation, most of the monastery rooms and the church are empty and have been waiting for many years for a sensible proposition for their use.

\section{III}

Although the monastic crypt in Lubiąz is the only one of its type known in Silesia, there are many places in Europe where the bodies of the deceased, mummified in a natural way, have been preserved to the present day. ${ }^{16}$ For the most part, these are dry and airy church or monastic crypts and underground chambers adapted for burial purposes where the bodies of the deceased were placed in coffins, directly on the floor or special shelves. As one might expect, most such monuments are located in southern Europe, where the dry Mediterranean climate is conducive to the process of the natural mummification of corpses. This is why the largest known group of mummified corpses in Europe, consisting of as many as 1,852 dead bodies, survived to the present times in the catacombs created by the Capuchin friary in Palermo, founded in 1532 (Figure 8). The first friar there, Silvestro de Gubbio, was entombed in 1599 in an underground chamber prepared for this purpose. This chamber was gradually

\footnotetext{
${ }^{13}$ Sightseeing takes place all year round in groups with a guide who leads visitors along the marked routes of the extensive facility every hour. See: www.fundacjalubiaz.org.pl/dla_zwiedzajacych.php.

${ }^{14}$ For more on the history of the Cistercian abbey in Lubiąż after 1810, see: BOLLMANN, Aloysius. Die Säkularisation des Zisterzienserstiftes Leubus. Breslau: Ostdeutsche Verlaganstalt 1932; KALINOWSKI, Konstanty. Lubiaż. Wrocław - Warszawa - Kraków: Zakład Narodowy im. Ossolińskich - Wydawnictwo 1970 (BRONIEWSKI, Tadeusz, ZLAT, Mieczysław (eds). "Śląsk w zabytkach sztuki”), passim; HARC, Artur, HARC, Lucyna, ŁUŻYNIECKA, Ewa. Lubiąż. In: WYRWA, Andrzej Marek. STRZELCZYK, Jerzy, KACZMAREK, Krzysztof (eds). Monasticon Cisterciense Poloniae, vol. 2: Katalog meskich klasžtorów cysterskich na ziemiach polskich i dawnej Rzecaypospolitej. Poznań: Wydawnictwo Poznańskie 1999, p. 202-217.

${ }^{15}$ KOWALSKI, Jacek M., KUDELSKI, Robert, REKUĆ, Zbigniew. Lubiqż: Na tropach wojennych tajemnic. Łódź: Biuro Odkryć 2003.

${ }^{16}$ WUNN, Ina. Mummies in monasteries and churches: monks, popes and princes. In: WIECZOREK, Alfried, ROSENTHAL, Wilfried (eds). Mummies of the world. The Dream of Eternal Life. Munich - Berlin - London - New York: Prestel 2010, p. 152-159.
} 


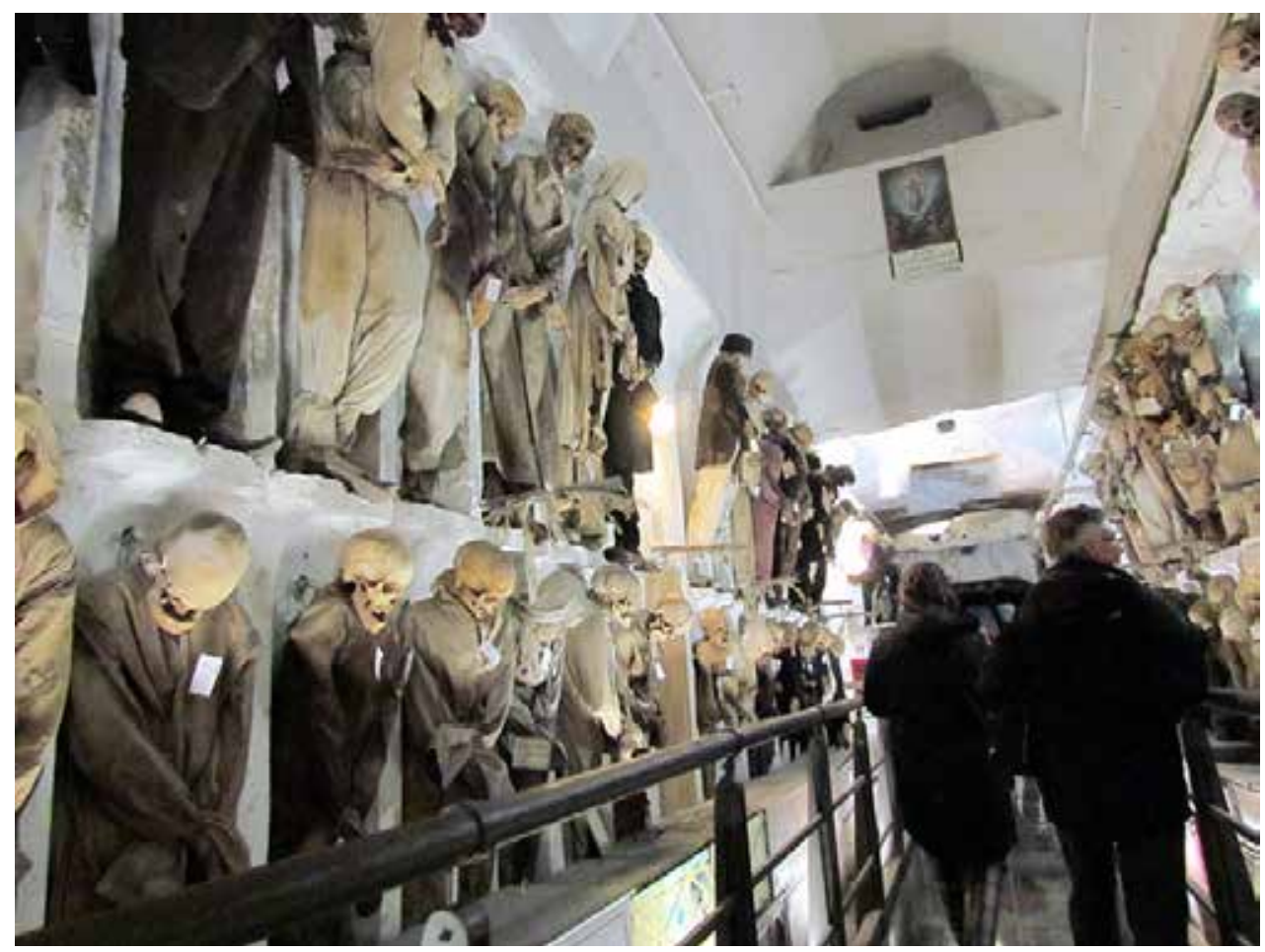

Figure 8: The catacombs at the Capuchin monastery in Palermo. Photograph by Wikimedia Commons

enlarged and functioned as a burial site until $1880 .{ }^{17}$ Similar, although less numerous, groups of mummies can be found in many other places in southern Europe. Suffice to mention that only in Italy have the mummified bodies of as many as 19 Christian saints been preserved, and some of them, such as the mortal remains of Saint Virginia Centurione Bracelli, who died in 1651, are still in excellent condition and have been placed in a special display case currently exhibited in the Cathedral Church of Genoa. ${ }^{18}$

However, there have also been groups of mummified corpses found to the north of the Alps. Although they are sometimes located in the crypts of palace chapels or parish and cathedral churches - the best example of which are the preserved mummy of Sophie Andrássy-Séredy in the chapel of Krásna Hôrka Castle in Slovakia ${ }^{19}$ and the so-called Lead Cellar (Bleikeller) discovered in 1698 in the basement of St Peter's Cathedral Church in Bremen ${ }^{20}$ - they were most often in the crypts of monastic churches. One of the oldest is a group of corpses preserved

\footnotetext{
${ }^{17}$ PIOMBINO-MASCALI, Dario, AUFDERHEIDE, Arthur C., PANZER, Stephanie, ZINK, Albert R. Mummies from Palermo. In: WIECZOREK, Alfried, ROSENTHAL, Wilfried (eds). Mummies of the world. The Dream of Eternal Life. Munich - Berlin - London - New York: Prestel 2010, p. 357-361.

${ }^{18}$ FULCHERI, Ezio. Mummies of Saints: a particular category of Italian mummies. In: SPINDLER, Konrad, WILFING, Harald, RASTBICHLER-ZISSERNIG, Elisabeth, ZURNEDDEN, Diether, NOTHDURFTER, Hans (eds). Human Mummies. A Global Survey of their Status and Techniques of Conservation. Wien-New York: Springer 1996, p. 219-230.

${ }^{19}$ BODORIKOVÁ, Silvia, BEŇUŠ, Radoslav, DÖRNHÖFEROVÁ, Michaela, HORVÁTHOVÁ-PRIPKOVÁ, Katarína, FUCHSOVÁ, Mária, MASNICOVÁ, Soňa. Pokus o identifikácju mumifikovaných l’udských telesných pozostatkov z hradu Krásna Hôrka (Okr. Rožňava, Slovensko). Slovenská antropológia, 20, 2017, p. 53-59.

${ }^{20}$ TACKE, Wilhelm. Bleikeller im Dom zu Bremen, oder der Dacbdecker, der kein Dacbdecker war. Bremen: Johann Heinrich Döll Verlag 1985.
} 


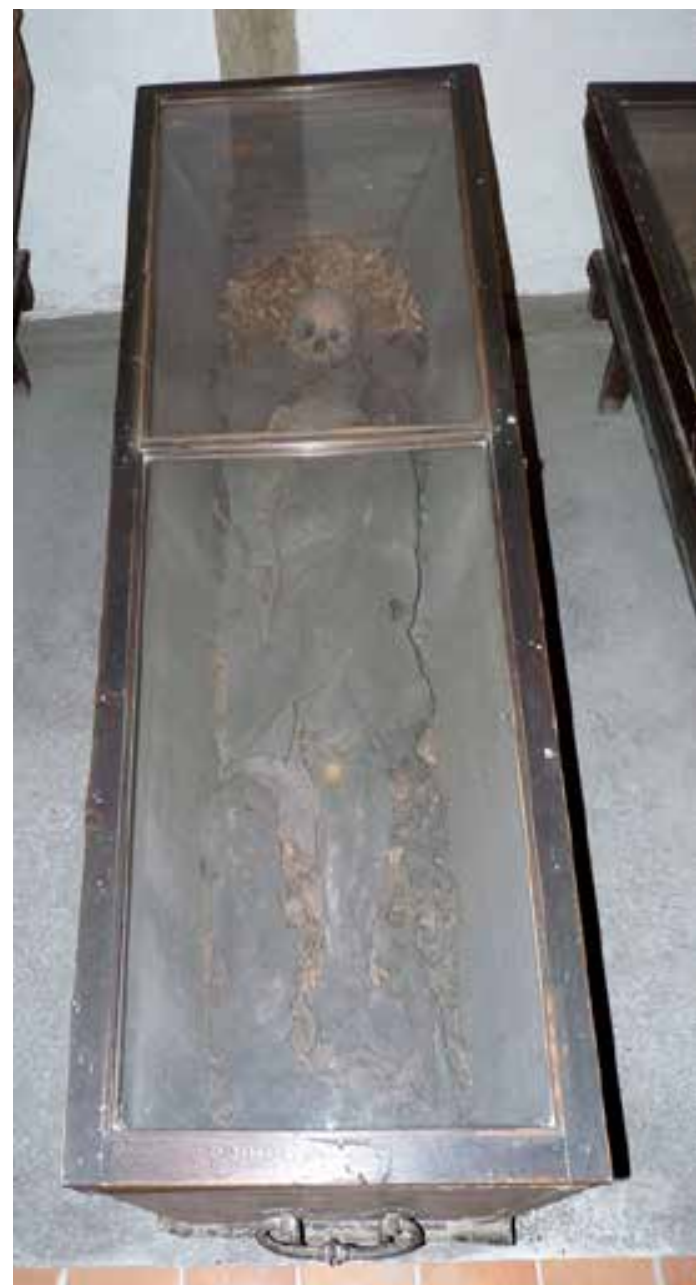

Figure 9: Glazed coffin with the mummified body of the architect Moritz Grimm, located in the crypt of the $\mathrm{Ca}$ puchin church in Brno.

Photograph by Michal Klajban, Wikimedia Commons

in the crypt of the monastery church of St Servacius in Quedlinburg, where the dead have been buried since the beginning of the eleventh century. One of the largest groups of preserved bodies in Central Europe, consisting of 265 human corpses, was found in a burial place which was accidentally discovered in 1994 during renovation works in the crypt of the Dominican monastery church in Vác in Hungary. ${ }^{21}$

According to the analysis of the preserved bodies and the content of historical accounts, not only monks but also lay people were placed in crypts after their deaths. Most often they were high-ranking people with associations to individual monasteries, perhaps as founders, patrons or benefactors. The best examples of this practice are those entombed in the basement of St Servacius Church in Quedlinburg, where the mummified mortal remains of the Saxon princes and their family members, starting with the Duke of Saxony and King of Germany, Henry I the Fowler (876-936) and his wife Matilda (895-968), are interred in adjacent crypts. ${ }^{22}$ However, it often happened that lesser members of the laity who belonged to the monastic parish and had been of service to the monastery were similarly interred. An example is the crypt underneath the Capuchin monastery church of the Finding of the Holy Cross in Brno, where bodies of the dead were placed from 1656 to 1784 . Among the approximately 200 mummified corpses gathered there were the mortal remains of approximately 50 lay people, including Baron Franz von der Trenck, the charismatic commanding officer of the Pandur troops, who died in 1749 in prison in the Brno fortress of Spielberg; and the local architect Mortiz Grimm (Figure 9), the author of the 1739 reconstruction of the crypt under the Capuchin monastery church, where he was interred together with his wife Ursula, his son Franz Anton and his daughter-in-law Maria Anna Josepha. ${ }^{23}$

A large proportion of the known crypts containing mummified bodies of the dead are open to the public. Sometimes public access is only on selected days of the year, in the form of a

\footnotetext{
${ }^{21}$ PAP, Idikó, SUZA, Éva, JÓZSA, László. Mummies from the $18^{\text {th }}-19^{\text {th }}$ century Dominican Church in Vác, Hungary. In: Acta Biologica Szegediensis, 42, 1998, p. 107-112.

${ }^{22}$ LABUSIAK, Thomas. Stiftskirche St. Servatii Quedlinburg. Dößel 2013.

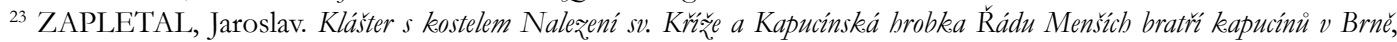
Brno: Fotep 2004.
} 
special tour of the crypt for a group of spectators. This is how one can visit the crypt in the Franciscans of Primitive Observance Church in Kraków, which contains about 60 preserved bodies from the years 1672-1870, and is open to the public on 2 and 3 November for only four hours. ${ }^{24}$ In general, however, places with preserved bodies of the deceased are open for sightseeing for most of the year, typically five or six days a week and for many hours a day. This applies to the largest and most interesting burial complexes in the catacombs at the Capuchin monastery in Palermo and the crypt of the Capuchin monastery in Brno. Visits to these places take place in groups with a guide (Palermo) or individually (Brno).

Of course, there are certain requirements involved in making sites with mummified bodies accessible to the general public. These requirements are based on the need to respect the site as the burial place of the deceased. It may involve the appropriate display of mummified corpses in special cases and glass coffins or in rooms separated from the public, with strict prohibitions on touching or photographing the corpses, using mobile phones, eating food and leaving rubbish. Another consideration is the need to maintain the specific microclimate inside the crypt which mummified the corpses and keeps them in this state. Therefore, humidity levels must be constantly monitored and the number of visitors and the frequency of visits limited to a level that will not disturb the delicate balance of the crypt's environment.

\section{IV}

There is nothing Polish law that stands in the way of making the crypt of the Cistercian monastery church in Lubiaż, along with the coffins with the mummified bodies of the monks and Willmann, available to the public. Polish law treats a corpse buried in its territory as a unique object which is nobody's property. It only imposes an obligation to treat it in an appropriate manner, that is, it prohibits desecrating or robbing the corpse, which in the penal code is considered a public order crime. ${ }^{25}$ What is more, according to the law on cemeteries, the Lubiazz monastic crypt is considered a closed cemetery, and such a cemetery can potentially be shut down after 40 years from its last burial, and its area used for a different purpose, provided that any objects of artistic, historical or archaeological value are preserved. ${ }^{26}$ Thus, the provisions of the Polish law allow for works to be carried out in the Lubiąz crypt in order to make it accessible to the public, but require that the mummified human corpses contained in it be treated appropriately. So what should be done?

There is no doubt that the religious crypt should retain its historical character as the burial place of the deceased, and all pro-exposure activities should be as limited as possible. Since the crypt space is relatively small, making it impossible to strictly separate visitors from the mummified bodies of the deceased, all of the bodies should remain locked in coffins, as before, and only a few should be adapted for exhibition purposes by replacing the lid of the

\footnotetext{
${ }^{24}$ SKOWROŃSKA, Małgorzata. Krypta z mumiami u reformatów na krótko otwarta, 29 X, 2009. In: www.krakow. wyborcza.pl.

${ }^{25}$ GARDOCKA, Teresa. Czy zwłoki ludzkie są rzeczą i co z tego wynika?. In: GOLACZYŃSKI, Jacek, MAZURKIEWICZ, Jacek, TURłUROWSKI, Jarosław, KARKUT, Daniel (eds). Non omnis moriar. Osobiste $i$ majatkowe aspek.ty prawne śmierci człowieka. Wybrane zagadnienia. Wrocław: Oficyna Prawnicza 2015, p. 268-280.

${ }^{26}$ AFFEK-BUJALSKA, Barbara. Podstawy prawne ochrony cmentarzy. In: MICHALOWSKI, Andrzej (ed.). Ochrona cmentarzy zabytkowych: materialy szkoleniowe pracowników Państwowej Stu̇̇by Ochrony Zabytków oraz materiały z konferencïi Organizacja lapidariów cmentarnych Żagań-Kożuchów 20-23 czernca 1993. Warszawa: Ośrodek Ochrony Zabytkowego Krajobrazu 1994 (“Studia i Materiały: Cmentarze”, 1), p. 27-32.
} 
coffin with glass. ${ }^{27}$ This group would include the coffins with the bodies of Willmann, those identified as being of Abbot Reich and Prior Hilbrich, and the six best-preserved mummies of the remaining anonymous monks. ${ }^{28}$ While the coffin with Willmann's body would remain in its current exposed position, the other glass-lidded coffins should be positioned along the passageway between the two rows of coffins leading from the entrance of the crypt to its western end, where Willmann's coffin is set. In this way, a simple tour route of this room would be created that makes it possible to see eight mummified monks (four on each side) as one approaches the greatest attraction of the crypt, which is undoubtedly the mummy of the "Silesian Apelles".

The tour of the Lubiąz crypt would take place only in guided groups and would be included in the permanent tour of the rest of the former Cistercian Abbey. Therefore, no information plaques would be introduced into the crypt, as they could interfere with its special character as a burial place of the dead. In any case, the small size of the room, with its low barrel vault, does not allow space for information boards. However, it would be necessary to install electric lighting and to conduct constant monitoring of the humidity levels in the crypt, allowing staff to potentially reduce the number of visitors if they were having negative impact on the microclimate of the room. Visitors would also be strictly forbidden from photographing the mummified corpses, using mobile phones, eating food or leaving rubbish. The opening of the crypt to the public would have to be accompanied by absolute respect for the corpses inside it.

This proposed project to adapt the Lubiąz monastic crypt to the requirements of an exhibition available to the public is not only in accordance with the Polish law, but also fully respects the guidelines for exhibiting human remains in museum facilities in Poland. According to the recommendations of the ICOM Code of Ethics, such remains should be "presented with the greatest sense of tact and with respect for human dignity common to all people". ${ }^{29}$ Unfortunately, Polish museums have yet to develop a detailed code of conduct with regards to human remains, such as, for example, the one that has been in force in the UK since $2005^{30}$ and in Germany since 2013. ${ }^{31}$ Generally, international discussion on ethical guidelines for exhibiting human remains is concentrated almost exclusively on museums and deals first of all with ancient mummies and archaeological findings. ${ }^{32}$ There is a lack of works which raise this issue in the context of the remains of early modern figures presented in monasteries or church interiors. In this field, we are forced to rely on our own sense and experience, as is the case with our proposition to assign a museum function to the currently empty Cistercian monastery church in Lubiąż (Figure 10) and to create the Michael Willmann Museum with his mummified body as

\footnotetext{
${ }^{27}$ This solution was used in the crypt of the Capuchin friary church in Brno, among others, in the case of the coffin of the architect Moritz Grimm (Fig. 9).

${ }^{28}$ These would the bodies in the coffins numbered 62, 64, 25, 36, 45, 63, 70 and 77. See: MISZKIEWICZ, ref. 10, p. $12-13$.

${ }^{29}$ See: JASTRZĘBSKA, Ewa. Prawne aspekty eksponowania szczątków ludzkich w muzeach polskich. In: Mužealnictwo, 56, 2015, p. 183-189.

${ }^{30}$ Guidance for the Care of Human Remains in Museums. Available at: http://webarchive.nationalarchives.gov.uk. See: CASSMAN, Vicki, ODEGAARD, Nancy, POWELL, Joseph. Human Remains: Guide for Museums and Academic Institutions. United Kingdom: Altamira Press 2007.

${ }^{31}$ Empfehlungen zum Umgang mit menschlichen Überresten in Museen und Sammlungen. In: http://www.museumsbund.de.

${ }^{32}$ See for example: ANTOINE, Daniel. Curating Human Remains in Museum Collections. Broader Considerations and a British Museum Perspective. In: FLETCHER, Alexandra, ANTOINE, Daniel, HILL, J. D. (eds). Regarding the Death: Human Remains in the British Museum. London: The British Museum 2014, p. 3-9.
} 


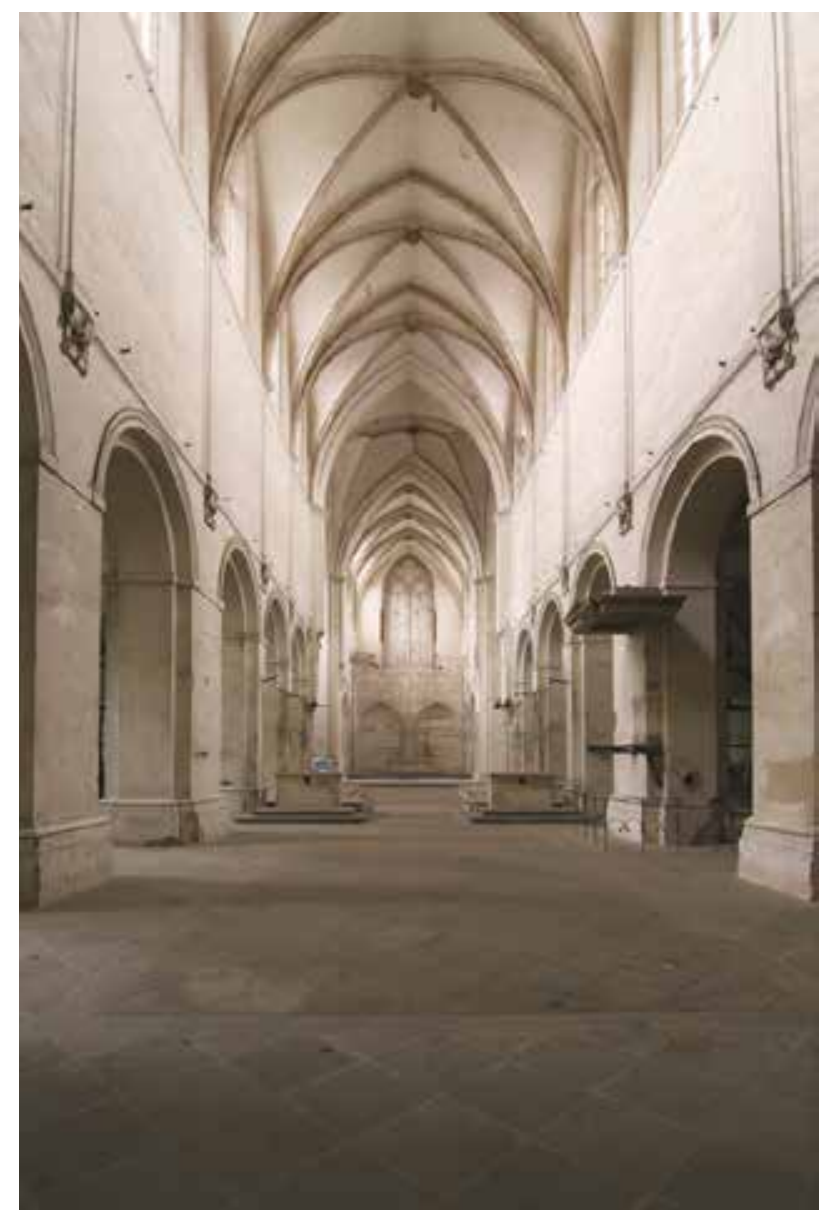

Figure 10: View of the former Cistercian church in Lubiaz, the current state. Photograph by Jerzy Buława one of the most important exhibits. ${ }^{33}$

Until 1943, there were at least 60 paintings by the artist and his workshop of various sizes and functions in the Lubiąż temple, which made up the largest complex of Baroque paintings in Central Europe made for a single church by a single artist assisted only by his collaborators. Therefore, the monastery's paintings were already, during Willmann's lifetime, treated as a kind of gallery his works, a situation which no other Central European painter of that time could boast of. Unfortunately, in 1943 , as part of the evacuation of the most valuable elements of the monastery's furnishings, most of Willmann's paintings were taken from the altars or removed from the walls of the church and transported to a hiding place in the Benedictine monastery church in Lubomierz, and then hidden in two unknown buildings in Szklarska Poręba Średnia. After the end of World War II, these works were not returned to Lubiąż and are now scattered in churches and museums across Poland. ${ }^{34}$

The idea behind creating a Michael Willmann Museum in the Cistercian monastery church in Lubiąż assumes that the original appearance of the interior of the Lubiąz church would be reconstructed on the basis of a rich collection of archival photographs (Figure 11) and technical drawings. ${ }^{35}$ In the current political climate, it is possible to return to the Lubiąz church not only the preserved paintings of Willmann and his workshop, but also other elements of its Baroque furnishings such as sculptures, stalls, the abbot's throne and the confessionals, which in most cases have also survived to the present day. Inside the church, these objects would become the basis of a unique museum exhibition in which any destroyed or lost elements of the original contents

\footnotetext{
${ }^{33}$ ORGANISTY, Adam, WYRZYKOWSKA, Małgorzata. Muzeum Willmanna, czyli “świątynia sztuki” w Lubiążu. Propozycje rewitalizacji kościoła klasztornego Wniebowzięcia NMP. In: KOZIEL, Andrzej (ed.). Kościót klasztorny Wniebowziecia NMP w Lubiaż. Historia - stan zachowania - koncepcja rewitalizacji, Wrocław: Wydawnictwo Uniwersytetu Wrocławskiego 2010, p. 149-166.

${ }^{34}$ See: KOZIEŁ, Andrzej (ed.). Kościót klasz̧torny Wniebowzięcia NMP w Lubiażu. Historia - stan zachowania - koncepcja rewitalizacji, Wrocław: Wydawnictwo Uniwersytetu Wrocławskiego 2010, p. 165-634.

35 These are the photographs and drawings from the former archive of Günther Grundmann, a pre-war Lower Silesian conservator. They are currently stored at the Herder-Institut in Marburg, the Art Institute of the Polish Academy of Sciences in Warsaw and the State Archive in Wrocław. See: KOZIEL, ref. 7, p. 134-135.
} 


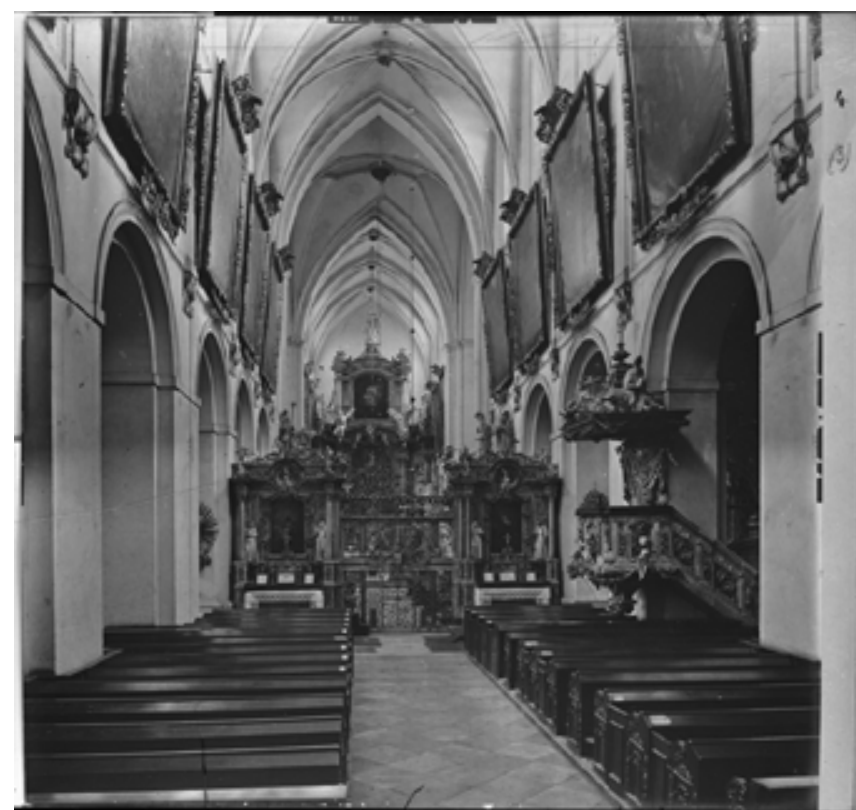

Figure 11: View of the former Cistercian church in Lubiac, before 1943. Photograph by Instytut Sztuki PAN in Warsaw would be recreated using modern multimedia tools.

Willmann's preserved mummy plays an extremely important role in the concept of this museum. Situated in a crypt open to the public, it would be, together with the mummified bodies of the monks, an eloquent testimony to the cultural heritage of the Lubiąz Cistercians and a unique museum exhibition, shown in its historical context and with full respect for the human remains. If created, the Michael Willmann Museum in the Cistercian monastery church in Lubiąż would most probably be the first museum exhibition in the world where a monastery's deceased patron and the author of most of the paintings exhibited in its interior would be physically present. After visiting Lubiąz, many visitors would be proud to say: I met Michael Willmann and admired his wonderful paintings.

Translated by Alicja Cimała

\section{References}

\section{Archival Sources}

Michael Willmann's family chronicle. In: RIVIUS, Gualtherus Hermenius. Der furnembsten notwendigsten der gantzen Architektur angehärigen mathematischen und mechanischen Künst eygentlicher Bericht und verstendliche Unterrichtung. Nürnberg: Peterius 1547, Prague, Strahovská knihovna, sign. AY XII 15.

Historia domestica Lubensis Notitiis praeclaris repleta Conscripta à Reverendo P. Arnoldo Professo Lubensi p: t: S.S. Theologiae Professore, [Leubus 1759], Wrocław, Biblioteka Uniwersytecka, rkps, sign. IV F. 209

Necrologium Lubense. Wrocław, Biblioteka Uniwersytecka, rkps, sign. IV. Fol. 214 and 215

\section{Contemporary publications}

AFFEK-BUJALSKA, Barbara (1994). Podstawy prawne ochrony cmentarzy. In: MICHALOWSKI, Andrzej (ed.). Ochrona cmentaryy zabytkowych: materiaty sqkoleniowe pracowników Państwowej S tużby Ochrony Zabytków oraz materialy z konferencji Organizacja lapidariów cmentarnych Żagań-Kożuchów 20-23 czerwca 1993. Warszawa: Ośrodek Ochrony Zabytkowego Krajobrazu ("Studia i Materiały: Cmentarze", 1), p. 27-32. 
ANTOINE, Daniel (2014). Curating Human Remains in Museum Collections. Broader Considerations and a British Museum Perspective. In: FLETCHER, Alexandra, ANTOINE, Daniel, HILL, J. D. (eds). Regarding the Death: Human Remains in the British Museum. London: The British Museum, p. 3-9.

BODORIKOVÁ, Silvia, BEŇUŠ, Radoslav, DÖRNHÖFEROVÁ, Michaela, HORVÁTHOVÁPRIPKOVÁ, Katarína, FUCHSOVÁ, Mária, MASNICOVÁ, Soňa (2017). Pokus o identifikácju mumifikovaných l’udských telesných pozostatkov z hradu Krásna Hôrka (Okr. Rožňava, Slovensko). Slovenská antropológia, 20, p. 53-59.

BOLLMANN, Aloysius (1932). Die Säkularisation des Zisterzienserstiftes Leubus. Breslau: Ostdeutsche Verlaganstalt.

CASSMAN, Vicki, ODEGAARD, Nancy, POWELL, Joseph (2007). Human Remains: Guide for Museums and Academic Institutions. United Kingdom: Altamira Press.

Empfehlungen zum Umgang mit menschlichen Überresten in Museen und Sammlungen. In: http://www.museumsbund.de

FUHRMANN, Heinrich (1966). Ich fotografierte Michael Willmann. In: Der Schlesier, 18, no. 4, p. 5.

FULCHERI, Ezio (1996). Mummies of Saints: A particular category of Italian mummies. In: SPINDLER, Konrad, WILFING, Harald, RASTBICHLER-ZISSERNIG, Elisabeth, ZURNEDDEN, Diether, NOTHDURFTER, Hans (eds). Human Mummies. A Global Survey of their Status and Techniques of Conservation. Wien-New York: Springer, p. 219-230.

GARDOCKA, Teresa (2015). Czy zwłoki ludzkie są rzeczą i co z tego wynika? In: GOŁACZYŃSKI, Jacek, MAZURKIEWICZ, Jacek, TURŁUROWSKI, Jarosław, KARKUT, Daniel (eds). Non omnis moriar. Osobiste i majatkowe aspekty prawne śmierci człowieka. Wybrane zagadnienia. Wrocław: Oficyna Prawnicza, p. 268-280.

Guidance for the Care of Human Remains in Museums. In: http:/ / webarchive.nationalarchives. gov.uk

HARC, Artur, HARC, Lucyna, ŁUŻYNIECKA, Ewa (1999). Lubiąż. In: WYRWA, Andrzej Marek. STRZELCZYK, Jerzy, KACZMAREK, Krzysztof (eds). Monasticon Cisterciense Poloniae, vol. 2: Katalog meskich klasætorów cysterskich na ziemiach polskich i dawnej Rzeczypospolitej. Poznań: Wydawnictwo Poznańskie, p. 202-217.

JASTRZĘBSKA, Ewa (2015). Prawne aspekty eksponowania szczątków ludzkich w muzeach polskich. In: Murealnictwo, 56, p. 183-189

KACZMAREK, Romuald, WITKOWSKI, Jacek (1990). Michał L.L. Willmann. Informacje dotyczące życia oraz pochówku w krypcie kościoła cysterskiego w Lubiążu. In: KALETYN, Tadeusz (ed.). Lubià், klasztor Cystersów. Wyniki badań z lat 1988-89. Wrocław: Wojewódzki Ośrodek Archeologiczno-Konserwatorski we Wrocławiu, p. 26-31.

KALETYN, Tadeusz (1990). Prace porządkowe archeologiczno-antropologiczne w krypcie grobowej w kościele NMP w Lubiążu. In: KALETYN, Tadeusz (ed.). Lubiqż klasztor Cystersów. Wyniki badań z lat 1988-89. Wrocław: Wojewódzki Ośrodek ArcheologicznoKonserwatorski we Wrocławiu, p. 6-8.

KALINOWSKI, Konstanty (1970). Lubiq $\dot{z}$. Wrocław - Warszawa - Kraków: Zakład Narodowy im. Ossolińskich - Wydawnictwo (BRONIEWSKI, Tadeusz, ZLAT, Mieczysław (eds). “Śląsk w zabytkach sztuki”). 
KOZIEL, Andrzej (2010). Losy wyposażenia i wystroju kościoła klasztornego Wniebowzięcia NMP w Lubiążu po 1943 roku. In: KOZIEŁ, Andrzej (ed.). Kościót klasžtorny Wniebowzięcia NMP w Lubiażu. Historia - stan zachowania - koncepcja rewitalizacji, Wrocław: Wydawnictwo Uniwersytetu Wrocławskiego, p. 137-138.

KOZIEL, Andrzej (2013). Michael Willmann i jego malarska pracownia. Wrocław: Wydawnictwo Uniwersytetu Wrocławskiego (“Acta Universitatis Wratislaviensis”, 3463, Historia Sztuki, 33).

LABUSIAK, Thomas (2013). Stiftskirche St. Servatii Quedlinburg. Dößel.

MISZKIEWICZ, Brunon (1990). Raport z prac porzqdkowo-segregacyjnych zmumifikowanych zwtok w krypcie w kościele NMP w Lubiqżu. In: KALETYN, Tadeusz (ed.). Lubiaż klasztor Cystersów. Wyniki badań z lat 1988-89. Wrocław: Wojewódzki Ośrodek Archeologiczno-Konserwatorski we Wrocławiu, p. 9-14.

MISZKIEWICZ, Brunon (1990). Identyfikacja szczątków Michaela Willmanna w krypcie

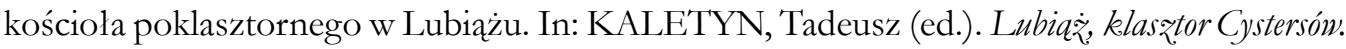
Wyniki badań z lat 1988-89. Wrocław: Wojewódzki Ośrodek Archeologiczno-Konserwatorski we Wrocławiu, p. 15-18.

ORGANISTY, Adam, WYRZYKOWSKA, Małgorzata (2010). Muzeum Willmanna, czyli "świątynia sztuki” w Lubiążu. Propozycje rewitalizacji kościoła klasztornego Wniebowzięcia NMP. In: KOZIE⿺, Andrzej (ed.). Kościót kelasðtorny Wniebowzৃięcia NMP w Lubiazৃu. Historiastan zachowania - koncepcja rewitalizacji, Wrocław: Wydawnictwo Uniwersytetu Wrocławskiego, p. 149-166.

PAP, Idikó, SUZA, Éva, JÓZSA, László (1998). Mummies from the $18^{\text {th }}-19^{\text {th }}$ century Dominican Church in Vác, Hungary. In: Acta Biologica Szegediensis, 42, p. 107-112.

PIOMBINO-MASCALI, Dario, AUFDERHEIDE, Arthur C., PANZER, Stephanie, ZINK, Albert R (2010). Mummies from Palermo. In: WIECZOREK, Alfried, ROSENTHAL, Wilfried (eds). Mummies of the world. The Dream of Eternal Life. Munich - Berlin - London New York: Prestel, p. 357-361.

SKOWROŃSKA, Małgorzata (2009). Krypta z mumiami u reformatów na krótko otwarta, 29 X. In: www.krakow.wyborcza.pl

TACKE, Wilhelm (1985). Bleikeller im Dom zu Bremen, oder der Dachdecker, der kein Dachdecker war. Bremen: Johann Heinrich Döll Verlag.

WELS, Paul (1909). Kloster Leubus in Schlesien. Breslau: Buchdruckerei der Schlesischen Volkszeitung.

WITKOWSKI, Jacek (1990). Inwentarz zabytków ruchomych odkrytych w krypcie kościoła

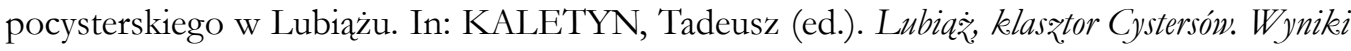
badań z. lat 1988-89. Wrocław: Wojewódzki Ośrodek Archeologiczno-Konserwatorski we Wrocławiu, p. 32-52.

WUNN, Ina (2010). Mummies in monasteries and churches: monks, popes and princes. In: WIECZOREK, Alfried, ROSENTHAL, Wilfried (eds). Mummies of the world. The Dream of Eternal Life. Munich - Berlin - London - New York: Prestel, p. 152-159.

ZAPLETAL, Jaroslav (2004). Kláster s kostelem Nalez̨eni sv. Křžęe a Kapucinská hrobka Řádu Menšich bratrí kapucinův Brně, Brno: Fotep. 